\title{
Bi-Sn (Bismuth-Tin)
}

\section{H. Okamoto}

The Bi-Sn phase diagram in [Massalski2] was adopted from [Hansen], who assessed the Bi-Sn phase diagram data published before 1958. Since then, more experimental data on this system were reported by [19580el], [1969Del], [1987Gla], and [2007Bra]. This system has been assessed thermodynamically by [1994Oht], [1996Lee], [2007Man], [2007Viz], and [2008Li].

[2007Bra] found that the solubility of $\mathrm{Bi}$ in $(\beta \mathrm{Sn})$ is much smaller (approximately half) than the values upon which most of these thermodynamic assessments were based. Figure 1 shows the Bi-Sn phase diagram calculated by [2007Viz], which reflects the result of [2007Bra].

\section{References}

19580el: W. Oelsen and K.F. Golücke, Thermodynamic Analysis, XI. Calorimetry and Thermodynamics of Bismuth-Tin Alloys, Arch. Eisenhüttenw., 1958, 29(11), p 689-698, in German

1969Del: J.C. Delabrouille and C. Lahanier, Under-Cooling of Tin-Bismuth Alloys, CR Acad. Sci. Paris, 1969, 268, p 884-887, in French
1987Gla: N.T. Gladkikh, S.P. Chiznik, V.I. Larin, L.K. Grigor'eva, A.L. Samsonik, and V.N. Sukhov, Structure of Binary Alloys in Condensed Films, Izv. Akad. Nauk SSSR, Metally, 1987, (1), p 176-184, in Russian, TR: Russ. Metall., 1987, (1), p 173-181

19940ht: H. Ohtani and K. Ishida, A Thermodynamic Study of the Phase Equilibria in the Bi-Sn-Sb System, J. Electron. Mater., 1994, 23(8), p 747-755

1996Lee: B.J. Lee, C.S. Oh, and J.H. Shim, Thermodynamic Assessment of the Sn-In and Sn-Bi Systems, J. Electron. Mater., 1996, 25(6), p 983-991

2007Bra: M.H. Braga, J. Vizdal, A. Kroupa, J. Ferreira, D Soares, and L.F. Malheiros, The Experimental Study of the Bi-Sn, Bi-Zn, and Bi-Sn-Zn Systems, Calphad, 2007, 31, p 468-478

2007Man: D. Manasijević, J. Vřšst'ál, D. Minić, A. Kroupa, D. Źivković, and Ź. Źivković, Phase Equilibria and Thermodynamics of the Bi-Sb-Sn Ternary System, J. Alloys Compd., 2007, 438, p 150-157

2007Viz: J. Vizdal, M.H. Braga, A. Kroupa, K.W. Richter, D. Soares, L.F. Malheiros, and J. Ferreira, Thermodynamic Assessment of the Bi-Sn-Zn System, Calphad, 2007, 31, p 438-448

2008Li: Z. Li, Z. Cao, S. Knott, A. Mikula, Y. Du, and Z. Qiao, Thermodynamic Investigation of the Ag-Bi-Sn Ternary System, Calphad, 2008, 32, p 152-163

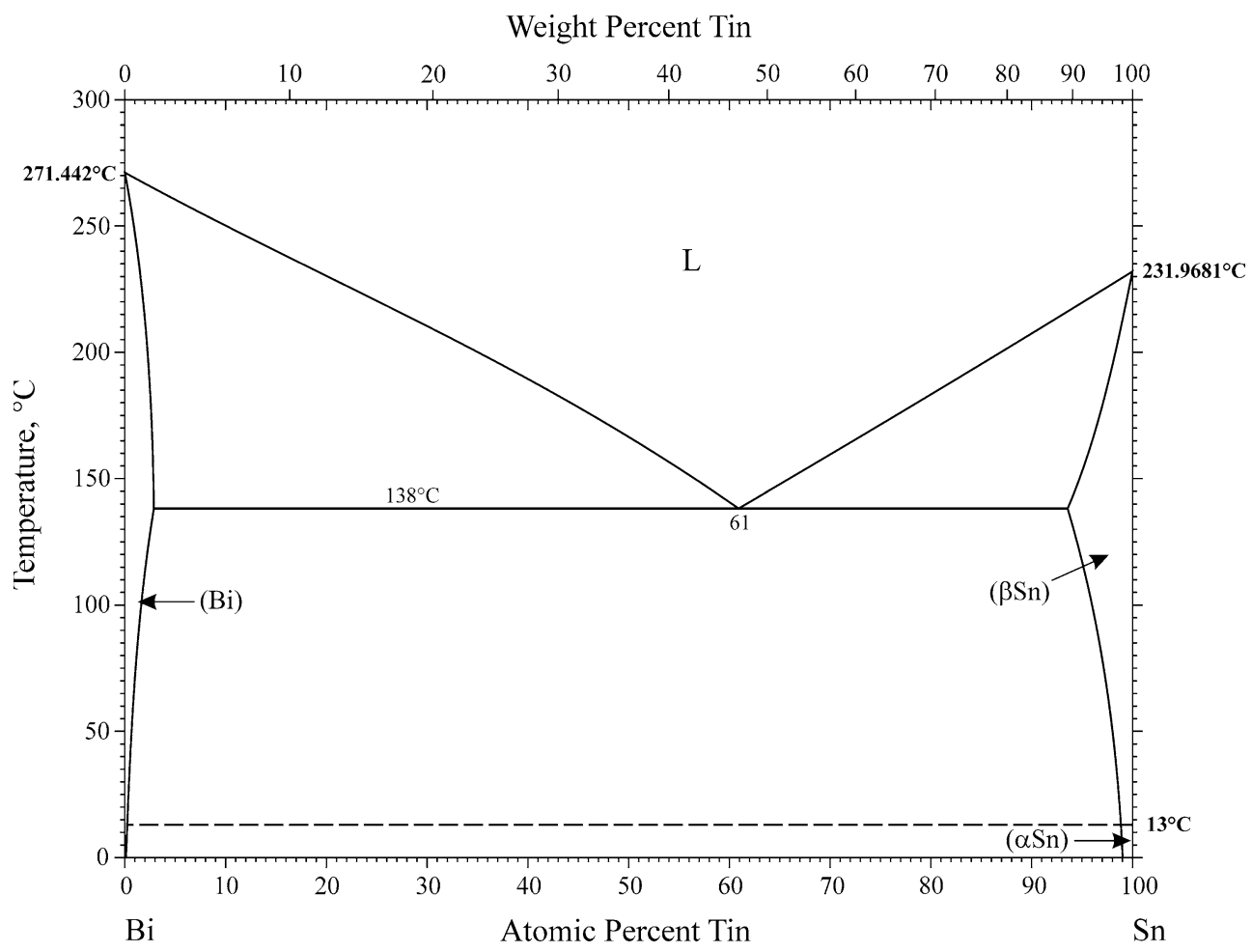

Fig. 1 Bi-Sn phase diagram 